\title{
100 years of genetics
}

\section{Alison Woollard ${ }^{1}$}

Received: 27 April 2019 / Accepted: 28 April 2019

(c) The Genetics Society 2019

The UK Genetics Society was founded on 25 June 1919 and this special issue of Heredity, a journal owned by the Society, celebrates a century of genetics from the perspectives of nine past (and present) presidents.

The founding of the Genetical Society (as it was then known) is often attributed to William Bateson, although it was actually the brain child of Edith Saunders. The enthusiasm of Saunders to set up a genetics association is cited in the anonymous 1916 report "Botany at the British Association", Nature, 98, 2456, p. 238. Furthermore, the actual founding of the Society in 1919 "largely through the energy of Miss E.R Saunders" is reported (anonymously) in "Notes", Nature, 103, 2596, p. 432, and Bateson wrote "it was Miss Saunders forced the Genetical Society upon us" in a letter to Lancelot Hogben in 1920 (copy held by John Innes Centre). Saunders studied Natural Sciences at Newnham College, Cambridge in the 1880s, although she didn't actually graduate, because in those days Cambridge University didn't award degrees to women (that had to wait until 1948!). Saunders did, however, benefit from Newnham's investment in the women-only Balfour Laboratory for teaching and research, and Saunders' work there allowed her to publish her first paper, entitled "On the structure and function of the septal glands of Kniphofia" (Saunders 1890). She began a lifelong collaboration with Bateson soon after, and in her first paper on heredity demonstrated "discontinuous variation" in the Buckler Mustard (Biscutella laevigata), in a paper communicated by Bateson in 1897 (Saunders 1897). This paper was important, because Saunders reported that her results called into question the "blending theory" widely accepted at the time, despite the publication of Mendel's work in 1865. Debate over the nature of inheritance at the turn of the 20th century put the "militant Mendelians" at odds with the

Alison Woollard

alison.woollard@bioch.ox.ac.uk

1 Department of Biochemistry, University of Oxford, Oxford, UK "biometricians"; the Genetical Society was very much a society of Mendelians. Remarkably, 16 of the original 87 members were women-virtually unknown in scientific societies at the time. Saunders was a vice president from its beginning and its 4th president from 1936-1938. Perhaps the new, and somewhat radical, ideas of "genetics" presented a rare opportunity for women to engage in research because the field lacked recognition in universities, and was therefore less attractive to men.

Bateson and Saunders (along with Punnett) were also influential in the field of linkage analysis ("partial coupling" as they referred to it at the time), having made several observations of its prevalence in various breeding schemes (Bateson et al. 1905). Saunders, for example, discussed "the existence of definite relationships between factors which are typically Mendelian in their behavior" (Saunders 1906). Bateson, however, wasn't at all keen on the chromosomal theory proposed by Morgan and colleagues, finding the idea that "particles of chromatin or of any substance, however complex" could influence ratios and transmission patterns "inconceivable" (Bateson 1919). Bateson and Punnett preferred the "reduplication view" based on the idea that factors didn't necessarily segregate simultaneously during cell division (Bateson and Punnett 1911). Saunders, on the other hand, quickly embraced the idea, spotting its extraordinary genius and giving it extensive consideration during her 1920 presidential address at the British Association for the Advancement of Science (BAAS). (The Report of the 88th meeting of the BAAS, Cardiff, 1920 can be found at https://archive.org/stream/reportofbritisha 20repo/reportofbritisha20repo.djvu.tx). After a lengthy exposition of Morgan's hypothesis, Saunders concludes "It must then be acknowledged that Morgan's interpretation of the cytological evidence has much in its favour. The striking parallel between the behavior of the chromosomes and the distributional relations of Mendelian allelomorphs is obvious. The existence in Drosophila ampelophila of four pairs of chromosomes and of four sets of linked characters can hardly be mere coincidence". The subsequent presence of Morgan and Sturtevant, and the widespread acceptance of their ideas, at the 11th meeting of the Genetical Society 
in 1922 is testament to the progressive and international ambitions that have always characterized the Society.

Saunders concluded her 1920 BAAS Presidential address thus:

"My appeal is for more organised co-operation in the experimental study of Genetics. It is a not uncommon attitude to look upon the subject of Genetics as a science apart. But the complex nature of the problems confronting us requires that the attacking force should be a composite one, representing all arms. Only the outworks of the fortress can fall to the vanguard of breeders. Their part done, they wait ready to hand over to the cytologists with whom it lies to consolidate the position and render our foothold secure. This accomplished, the way is cleared for the main assault. To push this home we urgently need reinforcements. It is to the physiologists and to the chemists that we look to crown the victory. By their co-operation alone can we hope to win inside the citadel and fathom the meaning of those activities which take shape daily before our eyes as we stand without and observe"

It is Saunders' model of organised cooperation that the Genetics Society embodies - at its inception and today, and the nine "presidential articles" featured in this special issue are testament to the power of open-minded collaboration, creativity and downright tenacity in attempting to solve some of the most complex, important and beautiful questions in biology.

Paul Nurse and Jacky Hayles deliver a master class on the nature of genetic investigation, focussed on studying cell cycle in fission yeast. They describe the power of the well thought-out forward genetic screen, the importance of creative imagination, making good choices, and the role of serendipity, the need to "commune" with the organism: all very human characteristics that we geneticists utterly rely on.

Jonathan Hodgkin takes us on a wondrous journey through his "Model Organism Diaspora", detailing the various successes - and importantly - the failures, in the quest of many geneticists to find the best model for their problem. Who knew, for example, that Delbruck championed the fungus Phycomyces blakesleeanus for its remarkable sensory abilities, but then found it was a bust when it came to sexual reproduction and transformation. Or that Mendel himself disappeared down a rabbit hole with the highly heterozygous and asexually reproducing hawkweed? Hodgkin also celebrates nature's many gifts to geneticists - the polytene chromosomes of Drosophila, feeding RNAi in Caenorhabitis elegans, the bountiful telomeres of Tetrahymena-before recalling his own adventures with the organisms, from worms to myxobacteria, through halobacteria and back to the worms again.
David Sherratt celebrates his life communing with bacteria, mostly Eschericia coli-working out basic principles of DNA replication, segregation, conjugation and recombination using his "observe - perturb - re-observe" mantra. There is so much to understand in bacteria that Sherratt, like David Hopwood, never felt the need to work on eukaryotes. Hopwood describes his life in Streptomyces, celebrating the crucial contributions that these bacteria have made to the search for new antibiotics. Hopwood also illustrates how the study of processes like conjugation and DNA replication in Streptomyces reveal mechanisms that are utterly different to the "E. coli paradigm"-offering us a glimpse into the extraordinarily diverse bacterial world. Streptomyces even have their own take on telomeres to deal with their linear chromosomes!

Laurence Hurst goes back to basics-re-evaluating Mendel's first law of equal segregation. We've all heard of dramatic examples of segregation distortion, but what effects do weak segregation bias-now detectable with technological advances-have on genotypes? How does this affect our understanding of evolution? Sticking with the quantitative theme, Brian Charlesworth is uncompromising on the importance of applying mathematical and statistical methodologies to evolutionary genetics. Authors, proposes Charlesworth, should not pronounce about evolution unless they have studied population genetics!

Wendy Bickmore and Veronica Van Heyningen take a genome-centered view. Bickmore discusses her work chasing down genes in the 1980s, and how she was captivated by chromosome bands during a temporary lab move to a cytogenetics department. This led to a career-long interest in genome organisation, and the arrangement of chromosomes within the nucleus. Bickmore reflects on how advancing technology allows for ever higher resolution analysis of chromosomal structures and domains, but the question remains-what do they all do? Van Heyningen takes us through the important history of genome sequencing from the unique viewpoint of someone who witnessed the remarkable transformation in technologies for DNA analysis that have turned the world of genetic research upside down and which have far-reaching implications for society.

Enrico Coen chose to depart from the shores of his familiar world of plant developmental genetics and think about the evolution of human intelligence. Coen argues that the emergence of storytelling for selective advantage allowed for an arms race between truth and deception, promoting conscious thought and planning. It is very fitting for this special issue to culminate in Coen's reflection that scientists engage storytelling principles to share their findings, founded on the principles of animal learning. 
And finally, Rico entertains with his short treatise on "Homo geneticus". You will love it!!

Is it too indulgent to suggest that there is something special about genetics? What other branch of science can break open a mystery in such style? What other discipline provides explanations on so many scales-from the molecule to the population? What else gets at who we are, and hints at where we might be going? I commend to you this wonderful collection of articles by some of the best geneticists in the UK, as a fitting tribute to the truly awesome power of genetics and 100 years of the Genetics Society.

Publisher's note: Springer Nature remains neutral with regard to jurisdictional claims in published maps and institutional affiliations.

\section{References}

Bateson W (1919) [in a review of The Mechanism of Mendelian Heredity by Morgan, Sturtevant, Muller and Bridges]. Science 44:536-543

Bateson W, Punnett RC (1911) On gametic series involving reduplication of certain terms. J Genet 1:293-302

Bateson W, Saunders ER, Punnett RC (1905) Experimental Studies in the Physiology of Heredity (Reports to the Evolution Committee of the Royal Society, Report II), pp. 4-99

Saunders ER (1890) On the structure and function of the septal glands in Kniphofia Ann Bot os-5(1):11-25

Saunders ER (1897) On a discontinuous variation occurring in Biscutella laevigata. Proc R Soc Lond 62:11-26

Saunders ER (1906) Certain complications arising in the crossbreeding of stocks (Royal Horticultural Society Report of the Third International Conference 1906 on Genetics), pp. 143-149 